\title{
Case Series of 10 Drug-Refractory IBS Patients Who Respond to Oral Serum-Derived Bovine Immunoglobulin/Protein Isolate (SBI)
}

\author{
Raouf Hilal1, Patricia Mitchell'2, Ernesto Guerra Jr.2, Bruce P. Burnett ${ }^{3 *}$ \\ ${ }^{1}$ Center for Advanced Gastroenterology, Maitland, USA \\ ${ }^{2}$ San Antonio Gastroenterology Associates, San Antonio, USA \\ ${ }^{3}$ Department of Medical Affairs, Entera Health, Inc., Cary, USA \\ Email: ${ }^{*}$ bruce.burnett@enterahealth.com
}

Received 7 August 2014; revised 23 September 2014; accepted 7 October 2014

Copyright (C) 2014 by authors and Scientific Research Publishing Inc.

This work is licensed under the Creative Commons Attribution International License (CC BY). http://creativecommons.org/licenses/by/4.0/

\section{Open Access}

\section{Abstract}

Aim: The responses of 10 patients with long-standing, symptomatic, intractable drug-refractory histories of irritable bowel syndrome with diarrhea (IBS-D) and with abdominal pain, gas/bloating and distention, termed IBS undefined (IBS-U), were evaluated when administering a medical food product containing serum-derived bovine immunoglobulin/protein isolate (SBI). Methods: Patients in this case series were chosen based on their lack of satisfactory response to a variety of drugs, including antidiarrheal and antispasmodic medications, serotonin 5-HT3 receptor antagonists, selective serotonin re-uptake inhibitors (SSRIs), proton pump inhibitors (PPIs), antibiotics, and antidepressive drugs. Patients met Rome III criteria and were administered $5 \mathrm{~g} / \mathrm{day}$ of SBI as standard-of-care nutritional support. A scale of $0 \%-25 \%, 25 \%-50 \%, 50 \%-75 \%, 75 \%-$ $100 \%$ response to SBI was used for patient-reported improvement in overall IBS symptoms following administration for one month. Exact methods for calculating confidence intervals and pvalues were used to assess complete management of symptoms and response to therapy. Adverse events were also monitored for this nutritional product. Results: The onset of gastrointestinal (GI) symptom reduction utilizing nutritional management with SBI occurred within an average time of 2-4 weeks with improved or near complete management in all 10 patients who were refractory to previous drug therapies by 4 weeks. When prompted, patients reported significant IBS symptom improvement which averaged between $50 \%-100 \%(p=0.002)$ with an average for complete management in all patients of $69 \%$. No side effects were reported after SBI administration even when taken for up to 28 weeks. Conclusion: Based on the safety profile and reported outcomes in

\footnotetext{
*Corresponding author.
} 
this case report, SBI should be considered as a nutritional option for management in IBS-D and IBS-U.

\title{
Keywords
}

\author{
Irritable Bowel Syndrome, Diarrhea, Gas, Bloating, Distention, Serum-Derived Bovine \\ Immunoglobulins
}

\section{Introduction}

The etiology of irritable bowel syndrome (IBS) is complex and not fully understood. Since there are no established bio-markers for IBS, diagnosis is via exclusion of underlying pathology and every "red flag" symptom. Irritable bowel syndrome is often a difficult to treat and an intractable problem for patients. Though the exact occurrence in developed countries is challenging to determine, it is estimated that $10 \%-20 \%$ of the population has IBS [1]-[3]. Only about $25 \%$ of patients seek professional health care [4] [5]. There are strong IBS symptom associations with altered gut microbiome, aberrant fermentation of short chain fatty acids, food sensitivities (e.g. gluten, lactose), bile acid malabsorption, gut-brain hypersensitivity through peripheral nerves, chronic low grade inflammation in the lamina propria and genetic susceptibility [6]. Due to its complex etiology, there is no single therapeutic option available with a robust safety profile and satisfactory efficacy in this population. Furthermore, patients often express a high level of dissatisfaction with their current therapies [7].

Dietary modification, by reducing the ingestion of fermentable oligosaccharides, disaccharides, monosaccharides, and polyols (FODMAP diet), has been shown to improve gastrointestinal (GI) symptoms [8] [9]. Conventional therapies often include drugs such as loperamide and diphenoxylate for diarrhea, laxatives for constipation, and antispasmodic/anti-cholinergic drugs (atropine and dicyclomine). Alternative therapies such as probiotics have also shown some effectiveness in reducing IBS symptoms, especially in IBS-C [10]. Though drug treatments such as nonabsorbable antibiotics, tricyclic antidepressants, and 5-HT3 receptor antagonists (alosetron) generally yield better IBS symptom relief compared with conventional therapeutics, they come with higher side effect profiles [11]. Safe and effective agents are still needed for the management of IBS.

SBI is a specially formulated protein mixture which provides for a distinctive dietary requirement in the management of enteropathy in patients with chronic loose or frequent stools in such conditions as IBS-D and HIV-associated enteropathy under physician supervision [12]. SBI is made up of approximately $92 \%$ protein, which includes $>50 \%$ immunoglobulin $\mathrm{G}$ (IgG) along with other proteins and peptides that reflect the composition of plasma and are similar to proteins found in colostrum and milk. The remaining composition of SBI is a small amount of water not removed in the drying process as well as a low percentage of minerals. This specially formulated protein mixture has a multifaceted mechanism of action which involves binding microbial components in the lumen, maintaining GI immune balance, managing gut barrier function, and improving nutrition utilization. A clinical study has been performed demonstrating the efficacy of SBI in IBS-D patients [13].

We present a retrospective case series of 10 IBS patients previously refractory to multiple drug therapies who were subsequently administered SBI and experienced significant improvement in overall symptoms, thereby corroborating the effectiveness of this nutritional product in a "real world" setting.

\section{Methods}

\subsection{Patients}

The Rome Foundation has defined three classes of IBS including irritable bowel syndrome with constipation (IBS-C), IBS-D, and alternating or mixed populations termed IBS-M [14]. In addition, there are patients who exhibit abdominal pain, gas/bloating, and distention, but do not necessarily fit within any of the three previous categorizations. For this analysis, these patients will be classified undetermined or IBS-U, although some physicians have used the term IBS-B (IBS-bloating). Nine of 10 patients in this case study were female. Patients were between the ages of 37 and 71 yrs with an average age of 58 (median 60.5 yrs). Patients in this analysis previously failed on multiple traditional pharmaceutical interventions and met the Rome III criteria [14]. Common to all patients in this case series were abdominal pain and bloating/distention with the exception of one (Case 
10), who lacked bloating and distention as part of their symptomology, but was diagnosed with IBS-D. Of the 10 patients, 6 cases were classified as IBS-D and 4 cases were classified as IBS-U. None of the patients reported constipation when questioned and their initial severity of GI symptoms varied from patient to patient prior to SBI administration. The patient demographics, their case history, gastrointestinal (GI) symptoms, and attempted treatments without resolution of symptoms are presented in Table 1.

Table 1. Case histories, gastrointestinal symptoms and previous treatments in patients.

\begin{tabular}{|c|c|c|c|c|c|c|}
\hline Case & $\begin{array}{l}\text { Age } \\
\text { (yrs) }\end{array}$ & Race & $\begin{array}{c}\text { Sex } \\
(\mathrm{M} / \mathrm{F})\end{array}$ & Case History & $\begin{array}{l}\text { Gastrointestinal } \\
\text { Symptoms }\end{array}$ & $\begin{array}{l}\text { Attempted Treatments without } \\
\text { Resolution of Symptoms }\end{array}$ \\
\hline 1 & 71 & $\mathrm{C}$ & $\mathrm{F}$ & $\begin{array}{l}\text { History of ischemic colitis, IBS-D } \\
\text { esophageal spasms/hypersensitivity, } \\
\text { Schatzki's ring, anxiety, and chronic } \\
\text { atypical chest pains, complaints of } \\
\text { hemorrhoids and irritation, rare } \\
\text { rectal bleeding from hemorrhoids, } \\
\text { rheumatoid arthritis }\end{array}$ & $\begin{array}{l}\text { Worsening epigastric pain, } \\
\text { general abdominal pain, } \\
\text { bloating/distension, diarrhea }\end{array}$ & $\begin{array}{l}\text { Pantoprazole, omeprazole, } \\
\text { sildenafil, atropine/ } \\
\text { hyoscyamine/scopolamine/ } \\
\text { phenobarbital, pantoprazole, } \\
\text { hyoscyamine, ondansetron, } \\
\text { promethazine, topical } \\
\text { hydrocortisone acetate }(2.5 \%)\end{array}$ \\
\hline 2 & 53 & $\mathrm{C}$ & $\mathrm{F}$ & $\begin{array}{l}\text { History of IBS-U, nausea, acid } \\
\text { indigestion, foul smelling flatus, } \\
\text { anemia, multiple somatic complaints }\end{array}$ & $\begin{array}{l}\text { Chronic abdominal pain, } \\
\text { bloating/distention, flatus, } \\
\text { epigastric pain, nausea }\end{array}$ & Dicyclomine, omeprazole \\
\hline 3 & 37 & $\mathrm{H}$ & $\mathrm{F}$ & $\begin{array}{l}\text { Lactose intolerance, small intestinal } \\
\text { bacterial overgrowth, IBS-U } \\
\text { symptoms }\end{array}$ & $\begin{array}{l}\text { Chronic abdominal pain, } \\
\text { bloating/distention, } \\
\text { diarrhea, positive } \mathrm{H} 2 \text { breath } \\
\text { test }\end{array}$ & $\begin{array}{l}\text { Pantoprazole, hyoscyamine, } \\
\text { polyethylene glycol } 3350 \mathrm{NF}, \\
\text { probiotic, flaxseed, subsequent } \\
\text { monthly courses of rifaximin } \\
\text { followed by dicyclomine }\end{array}$ \\
\hline 4 & 62 & $\mathrm{C}$ & $\mathrm{F}$ & $\begin{array}{l}\text { History lactose intolerance, IBS-U, } \\
\text { dyspesia/tachygastria, GERD, reflux } \\
\text { esophagitis, recurrent polycythemia } \\
\text { vera }\end{array}$ & $\begin{array}{l}\text { Chronic and severe } \\
\text { abdominal pain, } \\
\text { bloating/distention, with } \\
\text { occasional dyspepsia }\end{array}$ & $\begin{array}{l}\text { Aluminum hydroxide, magnesium } \\
\text { hydroxide and simethicone, milk } \\
\text { supplemented with lactase, } \\
\text { dicyclomine (discontinued due to } \\
\text { blurred vision) }\end{array}$ \\
\hline 5 & 59 & $\mathrm{~B}$ & $\mathrm{~F}$ & $\begin{array}{l}\text { History of IBS-D, GERD, insomnia, } \\
\text { sleep apnea }\end{array}$ & $\begin{array}{l}\text { Watery BMs with urgency, } \\
\text { abdominal pain and } \\
\text { distention relieved by } \\
\text { defecation, "bubbling" } \\
\text { followed by nausea/ } \\
\text { vomiting }\end{array}$ & $\begin{array}{l}\text { Escitalopram, amitriptyline, } \\
\text { alosetron caused nausea }\end{array}$ \\
\hline 6 & 63 & $\mathrm{C}$ & M & $\begin{array}{l}\text { Long history of IBS-D, GERD, } \\
\text { dyspesia/tachgastria, gastritis, } \\
\text { gastroparesis, anal fissure, hiatal } \\
\text { hernia, renal cell carcinoma }\end{array}$ & $\begin{array}{l}\text { Abdominal pain, } \\
\text { bloating/distention, diarrhea }\end{array}$ & $\begin{array}{l}\text { Omeprazole (discontinued), } \\
\text { diphenoxylate/atropine, } \\
\text { dicyclomine (discontinued), } \\
\text { tamsulosin, simvastatin, losartan, } \\
\text { simethicone }\end{array}$ \\
\hline 7 & 54 & $\mathrm{H}$ & $\mathrm{F}$ & $\begin{array}{l}\text { History of IBS-U, gastritis, GERD, } \\
\text { reflux esophagitis, hemorrhoids }\end{array}$ & $\begin{array}{l}\text { Chronic abdominal pain, } \\
\text { bloating/ distention, } \\
\text { nonulcer dyspepsia, } \\
\text { moderate epigastric pain } \\
\text { after meals }\end{array}$ & $\begin{array}{l}\text { Dicyclomine, hyoscyamine, } \\
\text { omeprazole, bisacodyl, } \\
\text { phenobarbital, PEG-3350 }\end{array}$ \\
\hline 8 & 52 & $\mathrm{C}$ & $\mathrm{F}$ & $\begin{array}{l}\text { History of gastroparesis and IBS-D } \\
\text { multiple somatic and joint } \\
\text { complaints }\end{array}$ & $\begin{array}{l}\text { Generalized abdominal } \\
\text { pain, bloating, early satiety, } \\
\text { chronic diarrhea, foul } \\
\text { smelling gas and flatulence, } \\
\text { bloating/distention, nausea, } \\
\text { vomiting }\end{array}$ & $\begin{array}{l}\text { Pantoprazole, ondansetron, } \\
\text { propranolol, } \\
\text { chlordiazepoxide/clidinium, } \\
\text { topiramate, quetiapine, } \\
\text { lamotrigine, sumatriptan, } \\
\text { trazodone }\end{array}$ \\
\hline 9 & 66 & $\mathrm{H}$ & $\mathrm{F}$ & $\begin{array}{l}\text { Long history of IBS-D, GERD, } \\
\text { gastritis, fundic gland gastric polyps, } \\
\text { avoids dairy }\end{array}$ & $\begin{array}{l}\text { Quit her part time job due to } \\
\text { symptoms, urgent exploding } \\
\text { diarrhea mainly in morning } \\
\text { with abdominal cramping, } \\
\text { fecal incontinence }\end{array}$ & Citalopram, bismuth subsalicylate \\
\hline 10 & 63 & $\mathrm{H}$ & $\mathrm{F}$ & $\begin{array}{l}\text { Long history of IBS-D, GERD, } \\
\text { gastritis }\end{array}$ & $\begin{array}{l}\text { Chronic watery, non-bloody } \\
\text { diarrhea with urgency } \\
\text { occurring } 2 \text { - } 3 \text { times a day }\end{array}$ & $\begin{array}{l}\text { Mesalamine (resulted in rash), } \\
\text { sulfasalazine, metronidazole, } \\
\text { methylprednisolone }\end{array}$ \\
\hline
\end{tabular}

C-Caucasian; B - Black (African American); GERD — Gastrointestinal Reflux Disease; H-Hispanic; IBS-D - Irritable Bowel Syndrome with Diarrhea; IBS-U—Irritable Bowel Syndrome Undefined (Abdominal Pain, Gas/Bloating/Distention); PEG-Polyethylene Glycol. 
Most patients had additional GI complications as well as other comorbidities which complicated their conditions detailed below.

Case 1 had a two-year history of IBS-D with worsening intermittent epigastric pain and ischemic colitis in addition to esophageal spasms and atypical chest pain. Case 2, in addition to being diagnosed as IBS-U for over one year, had multiple somatic complaints as well as nausea, epigastric pain and some flatus with a chronic history of stable anemia. Case 3 had a positive hydrogen breath test with lactose intolerance concurrent with small intestinal bacterial overgrowth (SIBO). The patient reported diarrhea, bloating, distention and gas pain and was diagnosed with IBS-D. During rifaximin (550 mg PO TID) treatment continuously for 5 weeks, symptoms were $50 \%$ better, but all symptoms returned with the same intensity after discontinuing the rifaximin course within 2 weeks. The patient then had a hydrogen breath test after the rifaximin course which was negative but symptoms continued. Case 4 had a two-year history of IBS-U complicated by lactose intolerance, dyspepsia/tachygastria, gastrointestinal reflux disease (GERD), reflux esophagitis, and had been treated with interferon for recurrent polycythemia vera. Case 5 had a one and a half-year history of IBS-D and GERD exacerbated by insomnia and sleep apnea. The patient reported the following symptoms after eating: cramping and abdominal pain followed by extreme urgency. Both cramping and abdominal pain were relieved by defecation, but the patient's quality of life continued to be severely altered because of the severity of symptoms. Case 6 had a three-year history of IBS-D along with GERD, dyspepsia/tachygastria, gastritis, gastroparesis, and anal fissures. In addition, this male patient, the only one in this case series, had a history of benign prostatic hyperplasia, hyperlipidemia, and hyperthyroidism as well as a history of renal cell carcinoma, which was fully encapsulated and removed without further treatment. Case 7 was diagnosed with IBS-U two years earlier, along with ongoing epigastric pain, GERD, reflux esophagitis, and non-ulcer dyspepsia. The patient also had comorbid liver/pancreas cystic nonmalignant neoplasms and multiple somatic and joint complaints. Case 8 was diagnosed with IBS-D over a year earlier, but also had gastrointestinal comorbidities of gastroparesis and ongoing rectal bleeding from hemorrhoids. The patient was additionally diagnosed with generalized anxiety, depression, bipolar disorder, fibromyalgia, hypertension, asthma and chronic obstructive pulmonary disease (COPD). Case 9 had a 10-year history of IBS-D complicated by GERD, gastritis, and fundic gland gastric polyps. Furthermore, the patient had comorbid hyperlipidemia, breast cancer (the treatment for breast cancer was successful and there was no evidence of disease upon follow up), and mitral valve prolapse. Finally, Case 10 had a 7-year history of IBS-D, GERD, and gastritis. Case 10 also had comorbid chronic non-specific colitis (previously diagnosed but unconfirmed by the current treating physician with follow up colonoscopy), a large cecal polyp (flat, benign, tubular adenoma, no high grade dysplasia or malignancy on pathology) which required a right hemicolectomy, hyperthyroidism, and hyperlipidemia. Because these patients had been refractory to multiple drug therapies, they were placed on SBI as a nutritional agent in an attempt to help manage their IBS. None of the treatments noted in Table 1 were used currently with SBI.

\subsection{Protocol}

Retrospective chart analysis was used to assess patient response to SBI administration as part of standard-of-care in patients diagnosed with drug-refractory histories for relief of symptoms for IBS-D and IBS-U. Patients were administered $5 \mathrm{~g} / \mathrm{d}$ for 4 weeks before being seen to assess the impact on management of IBS-D or IBS-U. After 4 weeks, patients were asked to report their overall response for symptom improvement to SBI as a nutritional support pro- duct using a tiered scale between $0 \%$ and $100 \%$. This scale was divided into four ranges $(0 \%-25 \%$, $25 \%-50 \%, 50 \%-75 \%, 75 \%-100 \%$ ) to assess patient-reported improvement in overall IBS symptoms (i.e., abdominal pain, diarrhea, gas/bloating/distention, flatulence) following administration of SBI for one month. Patients continued on product after 4 weeks to assess long term exposure and to assess adverse events in a few cases longer than 20 weeks. An exact method for calculating confidence intervals and p-values was used for the case series data with a lower bound $95 \%$ confidence interval to assess relative management of their condition and statistical response to this nutritional therapy. The cost of drugs patients were on before and after SBI administration was determined using a commercial site (www.goodrx.com) that provides the range of retail prices in the location where patients live. These prices were averaged to give the retail cost for patients around the practice where patients were seen by physicians.

\section{Results}

Three patients reported a response to nutritional management with SBI in the first 2 weeks. Seven others were 
not determined until the 4-week time point. All 10 patients responded to therapy within 4 weeks of receiving the first dose of 1 packet daily of EnteraGam ${ }^{\mathrm{TM}}(5 \mathrm{~g} / \mathrm{d}$ of SBI). Four of 6 patients with IBS-D reported a $75 \%$ $100 \%$ improvement in overall symptoms, while 2 out of 6 reported $50 \%-75 \%$ improvement at 4 weeks. One out of 4 patients with IBS-U reported a $75 \%-100 \%$ improvement in overall symptoms, while 3 out of 4 reported 50\%-75\% improvement at 4 weeks. Average time on SBI for all patients was 13.6 weeks (median $=10$ weeks). Using for calculating confidence intervals and the Fischer Exact test (two-sided) to calculate p-values for the case series data, the lower bound of the $95 \%$ confidence interval for the improved or near complete management rate among the cases in this study is $69 \%$. Testing of the overall rate against a null population proportion of $50 \%$ resulted in a significant reduction in gastrointestinal (GI) symptoms in these 10 refractory patients with a p-value of 0.002 . This represents a significant difference between patient responses to previous drugs vs. the response to nutritional management with SBI (Table 2).

Table 2. Observed response and improvement following serum-derived bovine immunoglobulin/protein isolate administration.

\begin{tabular}{|c|c|c|c|c|}
\hline Case & $\begin{array}{l}\text { Dose of SBI } \\
\quad(\mathrm{g} / \mathrm{d})\end{array}$ & $\begin{array}{l}\text { Initial Response and } \\
\text { Total Time on } \\
\text { Therapy (wks) }\end{array}$ & Symptom Response & $\begin{array}{l}\text { Overall Symptom } \\
\text { Improvement }\end{array}$ \\
\hline 1 & 5 & nd, 10 & $\begin{array}{l}\text { Significantly decreased symptoms including } \\
\text { bloating/distention, and diarrhea }\end{array}$ & $75 \%-100 \%$ \\
\hline 2 & 5 & nd, 24 & $\begin{array}{l}\text { Decreased bloating/distention and abdominal } \\
\text { pain }\end{array}$ & $50 \%-75 \%$ \\
\hline 3 & 5 & nd, 8 & $\begin{array}{l}\text { Improved abdominal pain, bloating/distention, } \\
\text { and diarrhea }\end{array}$ & $50 \%-75 \%$ \\
\hline 4 & 5 & nd, 4 & $\begin{array}{l}\text { Significant improvement in bloating and } \\
\text { distention }\end{array}$ & $75 \%-100 \%$ \\
\hline 5 & 5 & nd, 6 & $\begin{array}{l}\text { Decreased bloating, frequency, and urgency } \\
\text { sensation in less than one month on therapy. } \\
\text { One watery stool first followed by } 2 \text { soft stools } \\
\text { per day. Metronidazole } 10 \text {-day course and } \\
\text { dicyclomine as needed were prescribed along } \\
\text { with SBI. Now the patient is managed } \\
\text { continuously on SBI with loperamide as needed. }\end{array}$ & $75 \%-100 \%$ \\
\hline 6 & 5 & 2,10 & $\begin{array}{l}\text { In one week, bloating and diarrhea improved. } \\
\text { Continued improvement of bloating, diarrhea, } \\
\text { and symptoms of GERD over a } 9 \text { week period. } \\
\text { When patient stopped SBI for Nissen } \\
\text { Fundoplication, symptoms of bloating and } \\
\text { diarrhea returned. Re-initiation of SBI therapy } \\
\text { resolved symptoms once again after 2-weeks. }\end{array}$ & $75 \%-100 \%$ \\
\hline 7 & 5 & nd, 12 & Significant decrease in bloating and distention & $50 \%-75 \%$ \\
\hline 8 & 5 & nd, 24 & $\begin{array}{l}\text { Significant decrease in bloating in } 8 \text { wks with } \\
\text { continued improvement in abdominal pain, } \\
\text { bloating/distention and diarrhea thereafter. } \\
\text { Patient still has recurrent nausea with vomiting } \\
\text { and could not tolerate PPI therapy. Patient was } \\
\text { also placed on dicyclomine to manage condition. }\end{array}$ & $50 \%-75 \%$ \\
\hline 9 & 5 & 2,10 & $\begin{array}{l}\text { Bowel movements were formed after morning } \\
\text { meal with no urgency. Bismuth subsalicylate } \\
\text { was discontinued. No abdominal cramping was } \\
\text { reported after SBI administration. }\end{array}$ & $75 \%-100 \%$ \\
\hline 10 & 5 & 2,28 & $\begin{array}{l}\text { Normally formed bowel movements with } \\
\text { notably reduced urgency. Patient self trial off } \\
\text { SBI resulted in watery loose stool several times } \\
\text { a day. This was resolved with re-initiation of } \\
\text { SBI therapy within 2-weeks. }\end{array}$ & $50 \%-75 \%$ \\
\hline
\end{tabular}

GERD—Gastrointestinal Reflux Disease; nd—Not Determined; PPI—Proton Pump Inhibitor; SBI—Serum-Derived Bovine Immunoglobulin/Protein Isolate. 
Two patients completed an initial 4-week course of SBI (Cases 6 and 10) and had a return of IBS-D symptoms when they decided to discontinue product. When they re-initiated SBI, the symptoms subsided in approximately 2 weeks. Two patients (Cases 5 and 8) required co-administration with other agents to manage symptoms fully following the initial 4 weeks of SBI, suggesting a reduction in overall utilization of drug therapies to treat this real world population. Cost analysis utilizing an online tool for retail pricing (www.goodrx.com) demonstrated that these patients, on average, saved more than $\$ 300$ per month in direct drug costs and over $\$ 200$ in medical costs while on SBI in reduced office visits. Finally, all patients reported improved quality of life while on nutritional management with SBI.

\section{Discussion}

Wilson et al. [13] demonstrated in a single-center, randomized placebo-controlled study of subjects with IBS-D that SBI significantly reduced the number of days per week of symptoms such as abdominal pain, flatulence, bloating, loose stools, urgency and incomplete evacuation within the $10 \mathrm{~g} /$ day group. Efficacy within the $5 \mathrm{~g} /$ day group was also noted but to a lesser extent. The study was not powered for comparison against placebo (soy protein), however the placebo group showed no significant reduction in symptomatology. Due to a lack of information in drug-refractory IBS patients, this retrospective case series was undertaken to better understand the utility of SBI as a nutritional support product in a real world practice setting.

Patients with IBS represent a challenge not only to physicians in treating their condition, but also to healthcare systems in terms of cost of care. The financial burden this illness places on the United States is upwards of $\$ 10$ billion in direct medical costs and over $\$ 20$ billion in indirect medical costs, totaling greater than $\$ 30$ billion in combined costs per year [15]-[17]. It is estimated that patients with IBS utilize 50\% more healthcare resources than patients without this condition due to the need for significantly more physician office visits, repeated diagnostic tests, invasive procedures such as endoscopy and colonoscopy, and even a greater number of abdominal surgeries and cholecystectomy [18]-[20]. There is also a significantly higher utilization of multiple drug therapies for GI symptoms and psychological and somatic complaints in IBS patients [21] [22]. Patients with IBS experience poorer quality of life, resulting in limitations in day-to-day physical activities, decreases in social situations and increases in rates of depression [23]. IBS patients are prone to comorbidities of sleep disturbances, headaches, fibromyalgia, and psychological disorders. These conditions tend to overlap GI conditions such as functional dyspepsia, changes in motility, visceral hypersensitivity, GERD, celiac disease, and lactose intolerance [24]-[30]. Whether these comorbidities are causative, contributory, or linked to IBS is still a matter of debate.

IBS patients have disturbances in microbiota, minor inflammation in the lamina propria, barrier disruption and malabsorption of water [6]. SBI has been shown to bind to multiple microbes and components from these organisms which can induce enteropathy (for review, see [31]). Data from animal models demonstrate that the protein formulation decreases pro-inflammatory cytokines (i.e., TNF $\alpha$, IL-6), but also increases anti-inflammatory factors such as IL-10. In addition, models have shown that proteins in SBI manage gut barrier function through up-regulation of tight junction proteins. Finally, data from both animals and humans have shown that SBI decreases fecal fat and energy loss and increases protein as well as micronutrient uptake in recovering malnourished infants and children and D-xylose uptake in HIV patients with enteropathy [31].

The cases presented here are characteristic of IBS patients as a whole with food intolerances, somatic complaints, and sleep disturbance (Table 1). In particular, this group of patients also had a strong association with esophageal comorbidities and IBS symptoms. Esophagitis, GERD, dyspepsia/tachygastria, acid indigestion and esophageal spasms were present in 8 of 10 patients consistent with reported overlap of IBS with functional esophageal conditions [30]. Three patients in the study also experienced side effects to conventional drugs previously used to treat their IBS symptoms: blurred vision on dicyclomine, nausea from alosetron, and a rash while on mesalamine. There were no reported side effects for any patients on SBI, with every patient reporting improvement in IBS symptoms while on the product within 4 weeks and some reporting a response in as short time as two weeks. Finally, all patients reported a minimum of 50\% - 75\% improvement in symptoms with half (5 of 10) reporting $75 \%-100 \%$ improvement.

Despite this being a small retrospective chart analysis of patients that had not responded to previous treatments, it still resulted in a statistically significant decrease in IBS symptoms $(p=0.002)$ as well as pharmacoeconomic benefits with no reported side effects. Weaknesses of this case series report included that it was a re- 
trospective chart analysis with a small sample size of patients $(\mathrm{N}=10)$ and not a prospective evaluation. It is encouraging to note, however, that all patients responded to therapy by reporting improvement in their IBS symptoms, whereas they had experienced poor responses to traditional drug interventions.

Based on these results in a geographically separated, racially diverse population with comorbid disease complications and long histories of taking multiple agents for IBS, SBI was consistently effective in providing nutritional support to improve symptoms and the patients' quality of life. While additional research may be needed, SBI should be considered as a viable nutritional option for managing patients with IBS.

\section{Acknowledgements}

B.P.B wishes to acknowledge Douglas A. Drossman, M.D. for his critical reading of this manuscript and recommended edits.

\section{References}

[1] Lovell, R.M. and Ford, A.C. (2012) Prevalence of Gastro-Esophageal Reflux-Type Symptoms in Individuals with Irritable Bowel Syndrome in the Community: A Meta-Analysis. The American Journal of Gastroenterology, 107, 17931801. http://dx.doi.org/10.1038/ajg.2012.336

[2] Choung, R.S. and Locke, G.R. (2012) Epidemiology of IBS. Gastroenterology Clinics of North America, 40, 1-10. http://dx.doi.org/10.1016/j.gtc.2010.12.006

[3] Quigley, E.M., et al. (2012) A global Perspective on Irritable Bowel Syndrome: A Consensus Statement of the World Gastroenterology Organisation Summit Task Force on Irritable Bowel Syndrome. Journal of Clinical Gastroenterology, 46, 356-366. http://dx.doi.org/10.1097/MCG.0b013e318247157c

[4] Hungin, A.P.S., Chang, L., Locke, G.R., Dennis, E.H. and Barghout, V. (2005) Irritable Bowel Syndrome in the United States: Prevalence, Symptom Patterns and Impact. Alimentary Pharmacology Therapeutics, 21, 1365-1375. http://dx.doi.org/10.1111/j.1365-2036.2005.02463.x

[5] Drossman, D.A., Camilleri, M., Mayer, E.A. and Whitehead, W.E. (2002) AGA Technical Review on Irritable Bowel Syndrome. Gastroenterology, 123, 2108-2131. http://dx.doi.org/10.1053/gast.2002.37095

[6] Camilleri, M. (2012) Peripheral Mechanisms in Irritable Bowel Syndrome. The New England Journal of Medicine, 367, 1626-1635. http://dx.doi.org/10.1056/NEJMra1207068

[7] Drossman, D.A., Morris, C.B., Schneck, S., Hu, Y.J., Norton, N.J., Norton, W.F., Weinland, S.R., Dalton, C., Leserman, J. and Bangdiwala, S.I. (2009) International Survey of Patients with IBS: Symptom Features and Their Severity, Health Status, Treatments, and Risk Taking to Achieve Clinical Benefit. Journal of Clinical Gastroenterology, 43, 541-550. http://dx.doi.org/10.1097/MCG.0b013e318189a7f9

[8] Magge, S. and Lembo, A. (2012) Low-FODMAP Diet for Treatment of Irritable Bowel Syndrome. Gastroenterol Hepatol (NY), 8, 739-745.

[9] Halmos, E.P., Power, V.A., Shepherd, S.J., Gibson, P.R. and Muir, J.G. (2014) A Diet Low in FODMAPs Reduces Symptoms of Irritable Bowel Syndrome. Gastroenterology, 146, 67-75. http://dx.doi.org/10.1053/j.gastro.2013.09.046

[10] Hoveyda, N., Heneghan, C., Mahtani, K.R., Perera, R., Roberts, N. and Glasziou, P. (2009) A Systematic Review and Meta-Analysis: Probiotics in the Treatment of Irritable Bowel Syndrome. BMC Gastroenterol, 9, 15. http://dx.doi.org/10.1186/1471-230X-9-15

[11] Olden, K.W. (2012) Targeted Therapies for Diarrhea-Predominant Irritable Bowel Syndrome. Clinical and Experimental Gastroenterology, 5, 69-100. http://dx.doi.org/10.2147/CEG.S29023

[12] Petschow, B.W., Burnett, B.P., Shaw, A.L., Weaver, E.M. and Klein, G.L. (2014) Dietary Requirement for Serum-Derived Bovine Immunoglobulins in the Clinical Management of Patients with Enteropathy. Digestive Diseases and Sciences, Published Online. http://link.springer.com/article/10.1007\%2Fs10620-014-3322-0 http://dx.doi.org/10.1007/s10620-014-3322-0

[13] Wilson, D., Evans, M.D., Weaver, E., Shaw, A.L. and Klein, G.L. (2013) Evaluation of Serum-Derived Bovine Immunoglobulin Protein Isolate in Subjects with Diarrhea-Predominant Irritable Bowel Syndrome. Clinical Medicine Insights: Gastroenterology, 6, 49-60. http://www.ncbi.nlm.nih.gov/pmc/articles/PMC4020402/pdf/cgast-6-2013-049.pdf

[14] Longstreth, G.F., Thompson, W.G., Chey, W.E., Houghton, L.A., Mearin, F. and Spiller, R.C. (2006) Functional Bowel Disorders. In: Drossman, D.A., Corazziari, E., Delvaux, M., Spiller, R.C., Talley, N.J., Thompson, W.G., et al., Eds., Rome III: The Functional Gastrointestinal Disorders, 3rd Edition, Degnon Associates, McLean, 487-555.

[15] Talley, N.J., Gabriel, S.E., Harmsen, W.S., Zinsmeister, A.R. and Evans, R.W. (1995) Medical Costs in Community Subjects with Irritable Bowel Syndrome. Gastroenterology, 109, 1736-1741.

http://dx.doi.org/10.1016/0016-5085(95)90738-6 
[16] American Gastroenterological Association (2001) The Burden of Gastrointestinal Diseases. American Gastroenterological Association, Bethesda, 1-86. http://www.lewin.com/ /media/Lewin/Site_Sections/Publications/2695.pdf

[17] Martin, R., Barron, J.J. and Zacker, C. (2001) Irritable Bowel Syndrome: Toward a Cost-Effective Management Approach. The American Journal of Managed Care, 7, S268-S275.

[18] Longstreth, G.F., Wilson, A., Knight, K., Wong, J., Chiou, C.F., Barghout, V., Frech, F. and Ofman, J.J. (2003) Irritable Bowel Syndrome, Healthcare Use, and Costs: A US Managed Care Perspective. The American Journal of Gastroenterology, 98, 600-607. http://dx.doi.org/10.1111/j.1572-0241.2003.07296.x

[19] Lieberman, D.A., Holub, J., Eisen, G., Kraemer, D. and Morris, C.D. (2005) Utilization of Colonoscopy in the United States: Results from a National Consortium. Gastrointestinal Endoscopy, 62, 875-883. http://dx.doi.org/10.1016/j.gie.2005.06.037

[20] Longstreth, G.F. and Yao, J.F. (2004) Irritable Bowel Syndrome and Surgery: A Multivariable Analysis. Gastroenterology, 126, 1665-1673. http://dx.doi.org/10.1053/j.gastro.2004.02.020

[21] Miller, A.R., North, C.S., Clouse, R.E., Wetzel, R.D., Spitznagel, E.L. and Alpers, D.H. (2001) The Association of Irritable Bowel Syndrome and Somatization Disorder. Annals of Clinical Psychiatry, 13, 25-30. http://dx.doi.org/10.3109/10401230109147126

[22] Whitehead, W.E., Palsson, O. and Jones, K.R. (2002) Systematic Review of the Comorbidity of Irritable Bowel Syndrome with Other Disorders: What Are the Causes and Implications? Gastroenterology, 122, 1140-1156. http://dx.doi.org/10.1053/gast.2002.32392

[23] Gralnek, I.M., Hays, R.D., Kilbourne, A., Naliboff, B. and Mayer, E.A. (2000) The Impact of Irritable Bowel Syndrome on Health-Related Quality of Life. Gastroenterology, 119, 654-660. http://dx.doi.org/10.1053/gast.2000.16484

[24] Whitehead, W.E., Palsson, O.S., Levy, R.R., Feld, A.D., Turner, M. and Von Korff, M. (2007) Comorbidity in Irritable Bowel Syndrome. The American Journal of Gastroenterology, 102, 2767-2776. http://dx.doi.org/10.1111/j.1572-0241.2007.01540.x

[25] Jarrett, M., Heitkemper, M., Cain, K.C., Burr, R.L. and Hertig, V. (2000) Sleep Disturbance Influences Gastrointestinal Symptoms in Women with Irritable Bowel Syndrome. Digestive Diseases and Sciences, 45, 952-959. http://dx.doi.org/10.1023/A:1005581226265

[26] Chang, F.Y. and Lu, C.L. (2013) Irritable Bowel Syndrome and Migraine: Bystanders or Partners? Journal of Neurogastroenterology and Motillity, 19, 301-311. http://dx.doi.org/10.5056/jnm.2013.19.3.301

[27] Sperber, A.D., Akiva, S., Leshno, M., Halpern, Z. and Buskila, D. (2011) Validation of New Symptom-Based Fibromyalgia Criteria for Irritable Bowel Syndrome Co-Morbidity Studies. Journal of Neurogastroenterology and Motillity, 17, 67-72. http://dx.doi.org/10.5056/jnm.2011.17.1.67

[28] Lydiard, R.B., Fossey, M.D., Marsh, W. and Ballenger, J.C. (1993) Prevalence of Psychiatric Disorders in Patients with Irritable Bowel Syndrome. Psychosomatics, 34, 229-234. http://dx.doi.org/10.1016/S0033-3182(93)71884-8

[29] de Bortoli, N., Martinucci, I., Bellini, M., Savarino, E., Savarino, V., Blandizzi, C. and Marchi, S. (2013) Overlap of Functional Heartburn and Gastroesophageal Reflux Disease with Irritable Bowel Syndrome. World Journal of Gastroenterology, 19, 5787-5797. http://dx.doi.org/10.3748/wjg.v19.i35.5787

[30] Frissora, C.L. and Koch, K.L. (2005) Symptom Overlap and Comorbidity of Irritable Bowel Syndrome with Other Conditions. Current Gastroenterology Reports, 7, 264-271. http://dx.doi.org/10.1007/s11894-005-0018-9

[31] Petschow, B.W., Burnett, B., Shaw, A.L., Weaver, E.M. and Klein, G.L. (2014) Serum-Derived Bovine Immunoglobulin/Protein Isolate: Postulated Mechanism of Action for Management of Enteropathy. Clinical and Experimental Gastroenterology, 7, 181-190. http://dx.doi.org/10.2147/CEG.S62823 
Scientific Research Publishing (SCIRP) is one of the largest Open Access journal publishers. It is currently publishing more than 200 open access, online, peer-reviewed journals covering a wide range of academic disciplines. SCIRP serves the worldwide academic communities and contributes to the progress and application of science with its publication.

Other selected journals from SCIRP are listed as below. Submit your manuscript to us via either submit@scirp.org or Online Submission Portal.
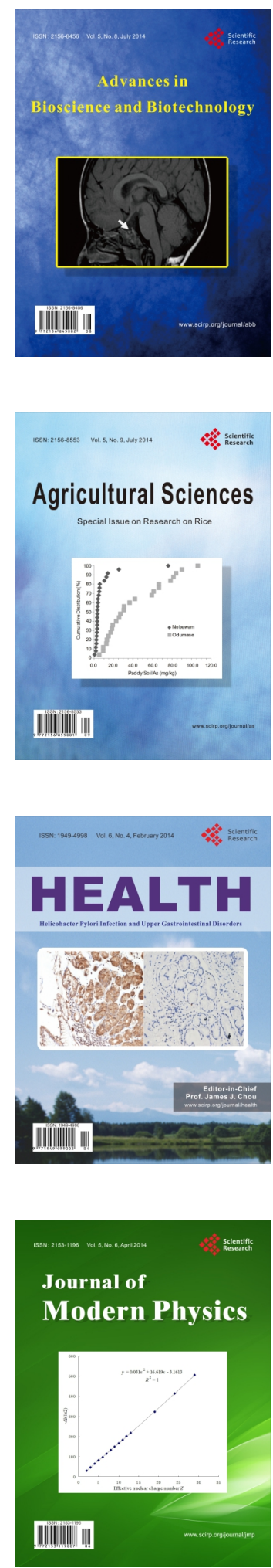
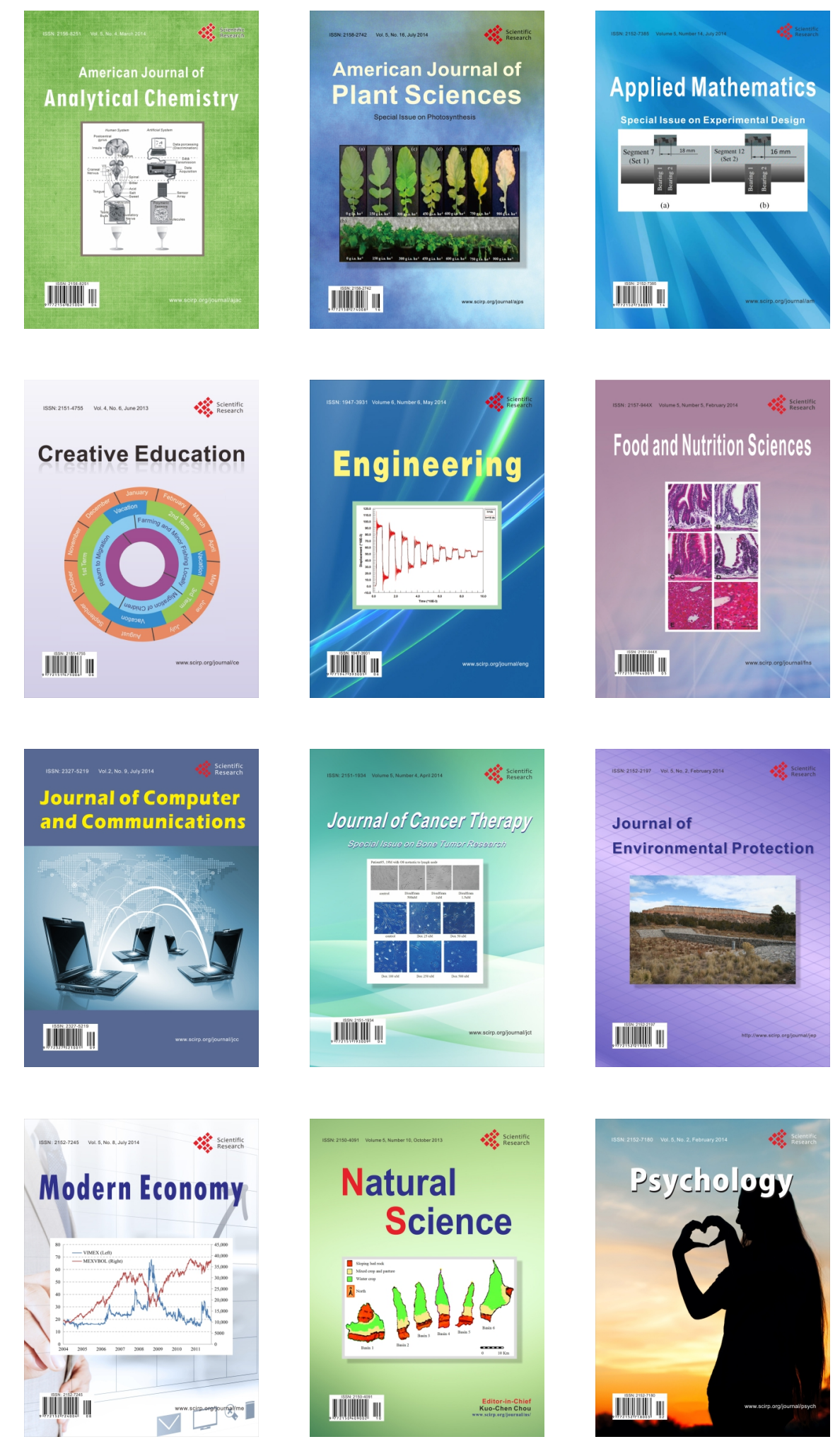